\title{
Current advances and ongoing researches in chest wall surgery
}

Thoracic surgery is a fascinating discipline for the pathophysiological problems it entails and for the variety of technical solutions it offers. Many sub-specialties are included in the disciplinary area of thoracic surgery, which are constantly evolving for the improvement of techniques and for the technological advancement of instruments and materials. Among these, chest wall surgery has certainly undergone a significant evolution in the last decade.

Reconstruction of the chest wall is indicated in a variety of clinical situations, as resection of primary or secondary tumors, correction of congenital deformities, treatment of infected wounds and repair of post-traumatic flail chest. Each of these indications involves specific management of both technical and biological problems (1).

The availability of new biological and synthetic materials reflects the progress of the scientific research in this field. Introduction into clinical practice of titanium as a material for chest wall reconstruction has been an important technical advance of recent years. The availability of such a light and resistant material has expanded the indications for the use of metallic prosthesis for repair of wide defects after tumor resection and for rib cage stabilization after trauma. However, a relatively high rate of implant failure with the currently available titanium devices has been reported, especially after rib osteosynthesis (2). Titanium bars and plates being currently of unbreakable and anelastic material, can produce fractures of the host bone at the implant fixation point, even after mild trauma. For this reason, more elastic titanium prostheses are in development, consisting of porous titanium connected to small rigid plates, which are used to fix the implant to the host bone. In such way, in the event of a crash, the elastic component of the prosthesis can absorb the traumatic shock wave, and in so doing help prevent the impact of the trauma at the level of the fixation points, lessening the likelihood of fracturing the host bones. Furthermore, new titanium meshes are now available, which seem to be elastic, easy to fix and pliable, and could represent a valid alternative to bar and plate prostheses, in selected patients (3).

Finally, the recent introduction of 3D printing technology in this surgical field allows for the building of customized chest wall prostheses, with remarkable improvement of the surgical planning, better implant fit and reduced operating times, owing to the fact that the material should no longer be shaped intra-operatively.

Indications for stabilization of rib fractures have been currently expanded after the introduction into the clinical practice of specific titanium devices, developed for this purpose. Patients with painful and displaced rib fractures can be successfully treated by open reduction and internal fixation, by titanium locking plates (4). Although incision and muscle division are currently minimized as much as possible, a thoracotomy is frequently performed to expose the fractured rib stumps. For such reason, one of the main concerns of these procedures is the added surgical trauma to an already traumatized patient. The development of minimally invasive procedures, effective for the rib osteosynthesis, has a strong rationale and research is focusing on this field to improve tools and techniques.

Another important advance in the prosthetic reconstruction of the chest wall is the use of both human and porcine bioprosthetic materials (5). Specifically, many reports on the favorable use of human cadaveric bone are available in the last years (6). The tissue is treated by irradiation and storage at $-80{ }^{\circ} \mathrm{C}$ in order to eliminate immunological properties and problems of histocompatibility of the graft. The allograft can be directly requested to the tissue banks, providing the patient's anthropometric data, in order to dispose of a perfectly fit and ready to use implant. This bone allograft proved to be an excellent prosthesis for reconstruction of the sternal region. We invited professor Rea and colleagues from the University of Padua (Italy) to send a contribution about their remarkable experience in this field. In 1996 one of us and colleagues had experimented a bovine bone, specifically treated to eliminate its antigenic properties, as prosthetic material for chest wall reconstruction. In this pioneering study the pathologic examination of the chest wall, after the sacrifice of the animal models, showed that the biologic implant was integrated into the host's tissues for an osteoconduction mechanism with buds of fresh vascular connective tissue growing into the grafted bone (7). These biological processes are assumed to be identical for the currently used human allograft, although there is no histological evidence to prove it.

Another important section of this special series on chest wall surgery has been dedicated to the prognostic factors of the resected lung cancer involving the chest wall. We invited two authoritative authors and their colleagues to share their experience with the CCTS readers, Dr. Lanuti from Boston and Dr. Alifano and colleagues from Paris (8). Furthermore, we 
added a study on the treatment of Superior Sulcus Tumors, focusing on some new technical details and on the outcome of multimodality regimens (9).

Again in terms of technical matters, the repair of full thickness chest wall defects can be improved by the cooperation between plastic and thoracic surgeons, especially in case of very extended resections (10). In this regard we invited Dr. Tukiainen and Dr. Salo from Helsinki to report their considerable experience with flap reconstruction of the chest wall after oncologic resection (11).

Finally, we are grateful to Dr. Phillips and colleagues from the Dartmouth Geisel School of Medicine for their interesting contribution on the management of a giant thoracic tumor (12).

In conclusion, chest wall surgery is an excellent research field, requiring continuous updating. Into such context, this special series should be inserted and it is our hope that this may be of interest for the CCTS readers.

\section{Acknowledgments}

We wish to thank the Editors-In-Chief, Dr. Gening Jiang and Dr. Douglas J. Mathisen, for entrusting us with this task. Funding: None.

\section{Footnote}

Provenance and Peer Review: This article was commissioned by the editorial office, Current Challenges in Thoracic Surgery for the special series "Surgical Management of Chest Wall Tumors". The article did not undergo external peer review.

Conflicts of Interest: Both authors have completed the ICMJE uniform disclosure form (available at https://ccts.amegroups. com/article/view/10.21037/ccts-2019-cwt-08/coif). The series "Surgical Management of Chest Wall Tumors" was commissioned by the editorial office without any funding or sponsorship. FP serves as an unpaid editorial board member of Current Challenges in Thoracic Surgery from March 2019 to March 2021 and served as the unpaid Guest Editor of the series. HCS serves as an unpaid Associate Editor-in-Chief of Current Challenges in Thoracic Surgery from January 2019 to December 2020 and served as the unpaid Guest Editor of the series.

Ethical Statement: The authors are accountable for all aspects of the work in ensuring that questions related to the accuracy or integrity of any part of the work are appropriately investigated and resolved.

Open Access Statement: This is an Open Access article distributed in accordance with the Creative Commons AttributionNonCommercial-NoDerivs 4.0 International License (CC BY-NC-ND 4.0), which permits the non-commercial replication and distribution of the article with the strict proviso that no changes or edits are made and the original work is properly cited (including links to both the formal publication through the relevant DOI and the license). See: https://creativecommons.org/licenses/by-nc$\mathrm{nd} / 4.0 \%$.

\section{References}

1. Puma F, Vannucci J. Chest wall resection/reconstruction for tumors. In: Mathisen DJ, Morse CR, Fischer JE, editors. Master Techniques in Surgery. Thorac Surg Philadelphia: W Kluwer, 2015:312-58.

2. Berthet JP, Gomez Caro A, Solovei L, et al. Titanium Implant Failure After Chest Wall Osteosynthesis. Ann Thorac Surg 2015;99:1945-52.

3. Tamburini N, Grossi W, Sanna S, et al. Chest wall reconstruction using a new titanium mesh: a multicenters experience. J Thorac Dis 2019;11:3459-66.

4. Suen HC. Open reduction and internal fixation of chest wall fractures. In: Mathisen DJ, Morse CR, Fischer JE, editors. Master Techniques in Surgery. Thorac Surg Philadelphia: W Kluwer, 2015:139-47.

5. Ely S, Gologorsky RC, Hornik BM, et al. Sternal Reconstruction With Non-Rigid Biologic Mesh Overlay. Ann Thorac Surg 
2020;109:e357-9.

6. Marulli G, Dell'amore A, Calabrese F, et al. Safety and Effectiveness of Cadaveric Allograft Sternochondral Replacement After Sternectomy: A New Tool for the Reconstruction of Anterior Chest Wall. Ann Thorac Surg 2017;103:898-905.

7. Puma F, Avenia N, Ricci F, et al. Bone heterograft for chest wall reconstruction after sternal resection. Ann Thorac Surg 1996;61:525-9.

8. Mazzella A, Loi M, Alifano M. Prognostic factors of resected lung cancer with chest wall involvement. Curr Chall Thorac Surg 2020;2:6.

9. Puma F, Gili A, Cagini L, et al. Surgery for Pancoast tumors-the role of combined approaches. Curr Chall Thorac Surg 2020;2:4.

10. Scarnecchia E, Liparulo V, Pica A, et al. Multidisciplinary approach to chest wall resection and reconstruction for chest wall tumors, a single center experience. J Thorac Dis 2017;9:5093-100.

11. Salo J, Tukiainen E. Flap reconstruction of the chest wall after oncologic resection. Curr Chall Thorac Surg 2020;2:5.

12. Fay K, Finley D, Phillips J. Giant posterior mediastinal schwannoma with ancient features. Curr Chall Thorac Surg $2020 ; 2: 9$.

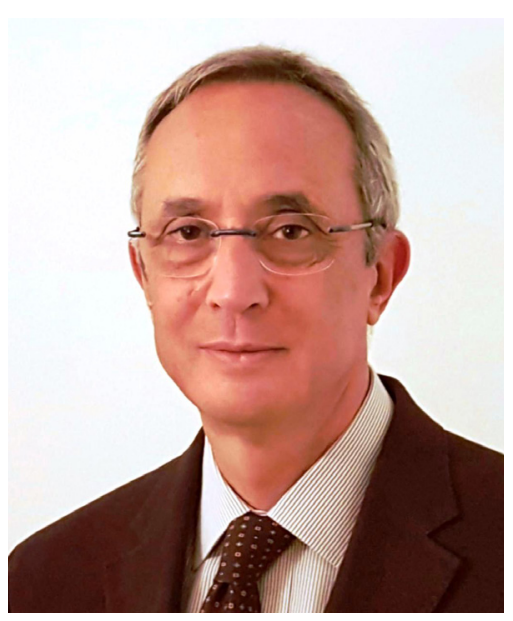

Francesco Puma

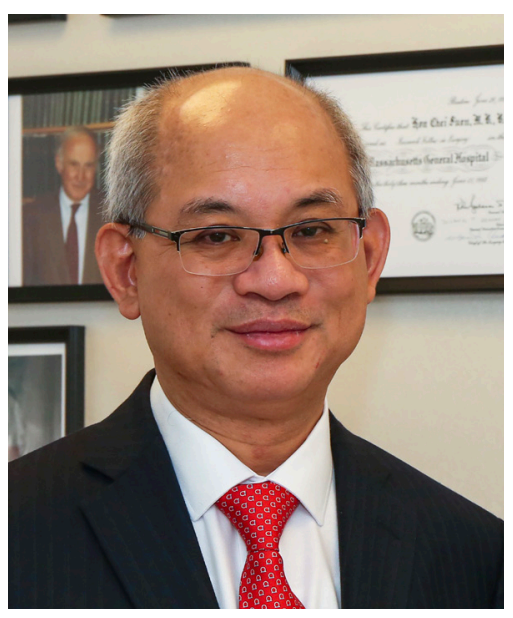

Hon Chi Suen

Francesco Puma, MD

Thoracic Surgery Department, University of Perugia School of Medicine, Perugia, Italy.

(Email: fr_puma@yaboo.it)

Hon Chi Suen, MBBS, FACS

Cardiothoracic Surgery Centre, Hong Kong Sanatorium \& Hospital, Hong Kong SAR, China.

(Email: bcsuen@gmail.com)

Received: 26 June 2020; Accepted: 20 July 2020; Published: 25 November 2020.

doi: $10.21037 /$ ccts-2019-cwt-08

View this article at: http://dx.doi.org/10.21037/ccts-2019-cwt-08

doi: $10.21037 /$ ccts-2019-cwt-08

Cite this article as: Puma F, Suen HC. Current advances and ongoing researches in chest wall surgery. Curr Chall Thorac Surg 2020;2:33. 